\title{
Effect of Zinc Deficiency on Mycobacterium tuberculosis var. bovis (BCG)
}

\author{
By JACQUELINE DE BRUYN,* MAURICE WECKX AND \\ MARIE-PAULE BEUMER-JOCHMANS \\ Institut Pasteur du Brabant, B-1040 Brussels, Belgium
}

(Received 16 June 1980; revised 7 November 1980)

\begin{abstract}
Mycobacterium tuberculosis var. bovis (BCG) grown on Sauton medium normally forms a pellicle; in the absence of added $\mathrm{Zn}^{2+}$, however, the pellicle sank during incubation and the yield was only about $20 \%$ of normal. The $\mathrm{Zn}^{2+}$-starved bacteria were morphologically similar to normal bacteria and were still acid-fast at $7 \mathrm{~d}$ as well as $14 \mathrm{~d}$. The $\mathrm{Zn}^{2+}$-starved bacteria had slightly higher free lipid and phospholipid contents than normal; the content of hexoses was lower and proteins slightly lower. The deficient culture medium became opalescent and alkaline. Aspartate and ammonium ions accumulated. There was twice as much protein in deficient as in normal medium; moreover, a class of proteins precipitable at $\mathrm{pH} 4 \cdot 5$, which was hardly detectable in normal medium, was present in appreciable amounts in deficient medium. The content of aldehydes, measured with yeast alcohol dehydrogenase, was also doubled in deficient medium. Fractionation of acid-soluble aldehydes obtained from deficient medium after acid treatment of a bisulphite precipitate suggested the presence of several complex molecules bearing aldehyde groups. The need for $\mathrm{Zn}^{2+}$ in the medium may be explained by the presence in normal BCG of a $\mathrm{Zn}^{2+}$-requiring NADP-dependent alcohol dehydrogenase activity whose affinity for aldehydes is especially high.
\end{abstract}

\section{INTRODUCTION}

Mycobacterium tuberculosis var. bovis (BCG) grows on the surface of Sauton medium and forms a yellow-grey folded pellicle which can be harvested for vaccine production. The medium remains limpid and becomes straw-yellow and slightly acid. Sometimes the culture grows poorly and forms a thin, pale, unfolded pellicle that gets wet and sinks, and the medium becomes opalescent and alkaline (up to $\mathrm{pH} \mathrm{8.8);} \mathrm{such} \mathrm{cultures} \mathrm{are} \mathrm{not} \mathrm{suitable} \mathrm{for} \mathrm{vaccine}$ production. Drea (1956) has shown that the wetting is linked to the use of some batches of glycerol and that the addition of small quantities of $\mathrm{Zn}^{2+}$ is sufficient to ensure good cultures. By omitting $\mathrm{Zn}^{2+}$ it is possible to obtain wet sunken cultures by choice. We have done this in order to determine the metabolic lesion(s) caused by $\mathrm{Zn}^{2+}$ deprivation and its effect on the composition of the bacteria and on the products excreted into the culture medium.

\section{METHODS}

Culture of bacteria. Mycobacterium tuberculosis var. bovis (BCG), French strain 1173P2, was grown on the surface of Sauton medium containing $5 \mu \mathrm{M}$-zinc sulphate. Media with or without $\mathrm{Zn}^{2+}$ were inoculated with portions of the same culture and incubated at $37.5^{\circ} \mathrm{C}$. After 7 or $14 \mathrm{~d}$, the cells were separated from the medium by filtration (in the presence of $\mathrm{Zn}^{2+}$ ) or by decantation and centrifugation (in the absence of $\mathrm{Zn}^{2+}$ ), and washed with phosphate-buffered saline (when used for enzyme preparation) or with physiological saline and then distilled water followed by freeze-drying (when used for chemical assays). Before analysis the culture media were centrifuged at $20^{\circ} \mathrm{C}$ for $10 \mathrm{~min}$ at $6000 \mathrm{~g}$ and then for $45 \mathrm{~min}$ at $26000 \mathrm{~g}$. After the second centrifugation, the opalescence of the $\mathrm{Zn}^{2+}$-deficient medium disappeared and a whitish pellet was obtained. This pellet was washed twice in saline. The clear normal medium showed no visible pellet. 
Chemicals were 'p.a.' products from Merck; enzymes and cofactors were from Boehringer. Freshly distilled water and Pyrex or Duran 50 glassware were used for the preparation of culture media and solutions to avoid $\mathrm{Zn}^{2+}$ contamination.

Chemical analysis of bacteria. Bacteria from $14 \mathrm{~d}$-old cultures were used in all analyses. Weights of freeze-dried bacteria were corrected for residual moisture estimated by the Karl Fisher method.

Total lipids were determined after acid hydrolysis $\left(5 \mathrm{~h}\right.$ at $100^{\circ} \mathrm{C}$ in $\left.6 \mathrm{M}-\mathrm{HCl}\right)$ and ether extraction as described by Kotani et al. (1959). Free lipids were extracted by the method of Bligh \& Dyer (1959) using two successive extractions, each for $2 \mathrm{~d}$, at room temperature and one extraction for $18 \mathrm{~h}$ at $37^{\circ} \mathrm{C}(1.5 \mathrm{ml}$ solvent per $10 \mathrm{mg}$ dried bacteria) and determined as described by Kotani et al. (1959). Lipid phosphorus was determined by the method of Ames (1966).

Proteins were determined by the micro-Kjeldahl technique as described by Chibnall et al. (1943).

For hexose determination, freeze-dried bacteria were hydrolysed in sealed ampoules under nitrogen in $1 \mathrm{M}-\mathrm{H}_{2} \mathrm{SO}_{4}$ at $100^{\circ} \mathrm{C}$ for $2 \mathrm{~h}$ and then hexose was determined with the anthrone reagent (Morris, 1948).

Enzyme assays. Preparation of cell-free extracts and the measurement of alcohol dehydrogenase activity were as described by De Bruyn et al. (1981). Glutamic-oxaloacetic transaminase (GOT) (EC 2.6.1.1) activity was measured as described by Karmen (1955) in $100000 \mathrm{~g}$ supernatants.

Chemical analysis of culture media. Medium for $14 \mathrm{~d}$-old cultures with or without added $\mathrm{Zn}^{2+}$ and samples of uninoculated medium (as controls) were analysed.

Ammonium ions were determined by the Nessler reagent (Charlot, 1961).

Free L-aspartate was determined with glutamic-oxaloacetic transaminase (Bergmeyer et al., 1974).

Proteins were measured by the Coomassie blue method (Spector, 1978) with the Bio-Rad reagent.

Aldehydes were measured using yeast alcohol dehydrogenase (EC 1.1.1.1) (Holzer \& Goedde, 1963). Alternatively, in preliminary assays, aldehydes and methylketones were isolated from media by precipitation with $30 \%$ sodium bisulphite (final concn) in the presence of $0.01 \mathrm{M}$-EDTA and $5 \%$ methanol. After $18 \mathrm{~h}$ at $4{ }^{\circ} \mathrm{C}$, the precipitates were sedimented and washed three times with $30 \%$ sodium bisulphite and once with ethanol at $4{ }^{\circ} \mathrm{C}$. Treatment of these precipitates with $0.1 \mathrm{M}-\mathrm{HCl}$ gave acid-soluble and acid-insoluble fractions which were separated by centrifugation. The acid-soluble material was either extracted with ether and concentrated to dryness or lyophilized. Dry material was dissolved in $0.05 \mathrm{M}$-ammonium acetate buffer $(\mathrm{pH} \mathrm{6.5)}$ and subjected to chromatography on a Sephadex G-15 column $(2.6 \times 50 \mathrm{~cm})$ at $4{ }^{\circ} \mathrm{C}$. Fractions containing aldehydes were first detected with Schiff reagent: 1 vol. Schiff reagent was added to 2 vol. samples of each fraction and allowed to react for several hours at room temperature. Schiff-positive fractions corresponding to peaks were pooled and analysed for carbonyl content with 2,4-dinitrophenylhydrazine as described by Daron \& Gunsalus (1962) except that the assay mixtures were incubated for $30 \mathrm{~min}$ at $70^{\circ} \mathrm{C}$ in sodium dodecyl sulphate (SDS; $0.1 \%$, w/v). Pooled fractions were also tested as substrates in an enzymic assay with yeast alcohol dehydrogenase and BCG $100000 \mathrm{~g}$ supernatant extract. The acid-insoluble fraction of $0.1 \mathrm{M}$-HCl-treated bisulphite precipitate was analysed by SDS-polyacrylamide gel electrophoresis (10 to $20 \%$, w/v, acrylamide gradient) as described by Laemmli (1970).

Addition of acetic acid to precooled culture media to lower the $\mathrm{pH}$ to 4.5 gave precipitates. After $18 \mathrm{~h}$ at $4{ }^{\circ} \mathrm{C}$, these precipitates were harvested by centrifugation and washed successively with $0.01 \mathrm{M}$-acetic acid/NaOH buffer (pH 4.5) and ethanol. This material was also analysed by SDS-polyacrylamide gel electrophoresis.

\section{RESULTS}

Effect of $\mathrm{Zn}^{2+}$ deficiency on growth and yields of BCG. Without addition of $\mathrm{Zn}^{2+}$, cultures sank and the medium became opalescent and alkaline (pH 8.3); the growth yield (measured as bacterial weight and total protein) was 20 to $25 \%$ of that obtained in the presence of $5 \mu \mathrm{M}-\mathrm{Zn}^{2+}$, which we considered to be normal growth conditions. A $\mathrm{Zn}^{2+}$ concentration of $2.5 \mu \mathrm{M}$ was sufficient to obtain pellicle culture, acidification of the medium ( $\mathrm{pH} \mathrm{6.44)}$ ) and $93 \%$ of normal protein yield. A $\mathrm{Zn}^{2+}$ concentration of $100 \mu \mathrm{M}$ gave $112 \%$ of the normal protein yield and a $\mathrm{pH}$ of $6 \cdot 26$. When $\mathrm{Zn}^{2+}(5 \mu \mathrm{M})$ was added after $7 \mathrm{~d}$ growth in deficient medium, the total protein yield after $14 \mathrm{~d}$ was $37 \%$ higher than without the addition of $\mathrm{Zn}^{2+}$; nevertheless the culture still sank.

The $\mathrm{Zn}^{2+}$-starved bacteria were morphologically similar to normal bacteria and were still acid-fast at $7 \mathrm{~d}$ as well as $14 \mathrm{~d}$.

Changes in composition of BCG grown in $\mathrm{Zn}^{2+}$-deficient medium. The content of some components of normal and $\mathrm{Zn}^{2+}$-starved bacteria are given in Table 1. Analysis of two different culture batches for total lipids did not show any significant difference between normal and $\mathrm{Zn}^{2+}$-starved bacteria (about $31 \%$ in each case). The $\mathrm{Zn}^{2+}$-starved bacteria had 
Table 1. Effects of $\mathrm{Zn}^{2+}$ deficiency on composition of BCG cells and culture medium

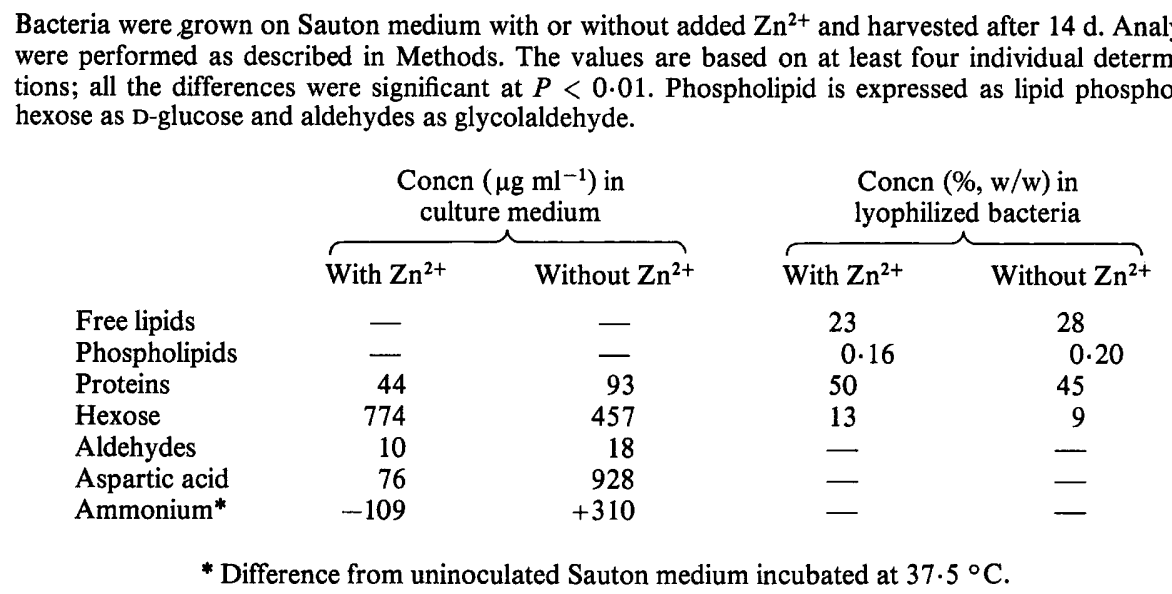

slightly higher free lipid and phospholipid contents. Protein and hexose contents were lowered.

A soluble NADP-dependent alcohol dehydrogenase activity with high affinity for aldehydes was found to be deficient in $\mathrm{Zn}^{2+}$-starved bacteria. In extracts from bacteria grown on deficient media the specific activity of this enzyme was $15 \%$ of its value in normal culture cells after $7 \mathrm{~d}$ or $14 \mathrm{~d}$ growth.

We also looked for an effect of $\mathrm{Zn}^{2+}$ deficiency on the activity of glutamic-oxaloacetic transaminase, which is responsible for L-glutamate biosynthesis in BCG growing on Sauton medium using asparagine as nitrogen source. The activity of the transaminase was lowered by $\mathrm{Zn}^{2+}$ deficiency to 45 to $50 \%$ of the activity of normal cultures of the same age ( 7 or $14 \mathrm{~d}$-old).

Composition of medium after growth of BCG under normal and $\mathrm{Zn}^{2+}$-deficient conditions. Free aspartate accumulated in $\mathrm{Zn}^{2+}$-deficient growth medium in very high amounts (about 12 -fold higher than normal) together with ammonium ions (Table 1); this confirms previous observations made on spontaneously sunken BCG cultures (Bance, 1942).

The amount of aldehydes measured with yeast alcohol dehydrogenase was about twice as high in the deficient medium as in the normal medium. Fractionation on Sephadex G-15 of the acid-soluble ether-extractable (as interface material) aldehydes originating from deficient medium gave a few major peaks with $K_{\mathrm{AV}}$ values ranging from 0.2 to 3 . Four fractions with $K_{\mathrm{AV}}$ values of $0.5,1.1,1.3$ and 1.8 , respectively, were tested as substrates for yeast alcohol dehydrogenase and BCG $100000 \mathrm{~g}$ supernatant extract. Only the fraction with a $K_{\mathrm{Av}}$ value of 1.1 gave a reaction with yeast alcohol dehydrogenase, in good correlation with the carbonyl content determined chemically. All four fractions tested gave NADPH oxidation with BCG $100000 \mathrm{~g}$ supernatant but NADPH oxidation was much higher than would have been expected on the basis of the carbonyl content determined chemically. Acid-soluble ether-extractable aldehydes were less abundant in normal medium than in low- $\mathrm{Zn}^{2+}$ medium.

Total proteins were at least twice as abundant in $\mathrm{Zn}^{2+}$-deficient medium as in normal medium. The fraction of these proteins precipitated at $\mathrm{pH} 4.5$ was much higher in deficient medium than in normal medium; it represented up to $8 \%$ of the protein content of normal medium but up to $67 \%$ of the protein content of the deficient medium. SDS-polyacrylamide gel electrophoresis of equal amounts of proteins precipitated at $\mathrm{pH} 4.5$ from normal and deficient media showed a very different pattern; in particular a component of approximately 66000 molecular weight was scarcely detectable in the normal medium, but accumulated in the deficient culture medium. This component was already abundant at $7 \mathrm{~d}$ (Fig. 1). 


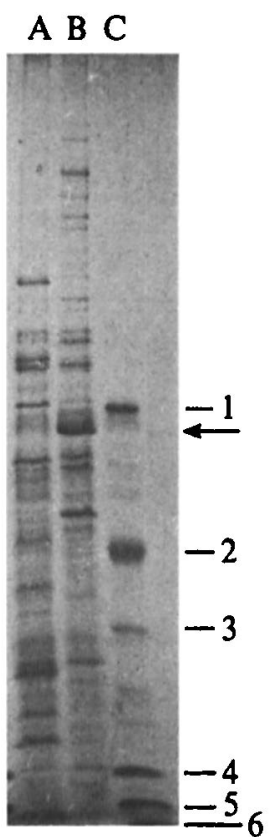

(a)

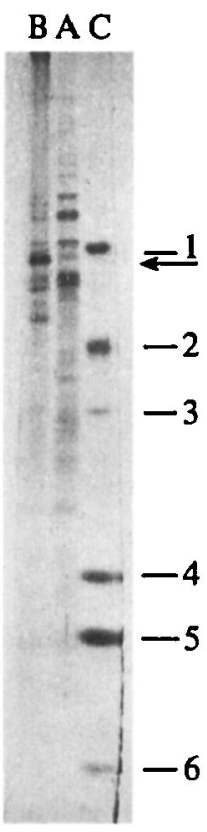

(b)

Fig. 1. SDS-polyacrylamide gels after electrophoresis of proteins precipitated at $\mathrm{pH} 4.5$ from media after $7 \mathrm{~d}$ growth $(a)$ or $14 \mathrm{~d}$ growth $(b)$. BCG was grown in Sauton medium with or without added $\mathrm{Zn}^{2+}$, and after sedimenting the bacteria, acid-precipitable proteins were isolated from the supernatant medium as described in Methods. A, proteins $(7.5 \mu \mathrm{g})$ from normal medium, i.e. with added $\mathrm{Zn}^{2+} . \mathrm{B}$, proteins $\left(7.5 \mu \mathrm{g}\right.$ ) from $\mathrm{Zn}^{2+}$-deficient medium. C, markers: 1, bovine serum albumin (mol. wt 68000 ); 2, ovalbumin $(45000) ; 3, E$. coli asparaginase $(33000) ; 4$, tobacco mosaic virus $(17000) ; 5, E$. coli lysozyme (14400); 6, insulin (7000). The arrows indicate the 66000 molecular weight component accumulated in $\mathrm{Zn}^{2+}$-deficient medium.

SDS-polyacrylamide gel electrophoresis of the acid-insoluble fraction of $\mathrm{HCl}$-treated bisulphite precipitate gave an identical pattern to the one obtained for $\mathrm{pH} \mathrm{4.5-precipitable}$ proteins.

The pellet obtained after centrifugation of medium from a $\mathrm{Zn}^{2+}$-deficient culture for $45 \mathrm{~min}$ at $26000 \mathrm{~g}$ consisted largely of polysaccharides rich in hexose $\left(0.6\right.$ to $0.8 \mu \mathrm{g} \mathrm{ml}^{-1}$ of the original medium); no glucosamine or protein could be detected. No such pellet was formed in normal culture medium.

\section{DISCUSSION}

We have observed (unpublished results) that after homogenization of comparable amounts of normal and $\mathrm{Zn}^{2+}$-starved bacteria by the standard procedure used for BCG vaccine production using steel balls, followed by centrifugation, the supernatant obtained from normal bacteria is pale yellow and turbid while the supernatant from $\mathrm{Zn}^{2+}$-starved bacteria is whitish and only half as turbid; this suggested that loosely attached surface components were lacking in $\mathrm{Zn}^{2+}$-starved bacteria. Furthermore, the observed liberation of polysaccharides in $\mathrm{Zn}^{2+}$-deficient opalescent medium and the slightly higher content of free lipids and phospholipids of the $\mathrm{Zn}^{2+}$-starved bacteria (Table 1) suggested an alteration of the cell wall. However, the $\mathrm{Zn}^{2+}$-starved bacteria were still acid-fast after 7 and $14 \mathrm{~d}$.

Although only slight differences in the contents of several bacterial components were found, the values reported were consistent for several independent cultures. Aldehyde accumulation and consequent possible deficiency in some esterifiable alcohols (possibly on hydrophilic 
molecules) could be responsible for the slightly higher free lipid content (possibly free fatty acid) of $\mathrm{Zn}^{2+}$-starved bacteria.

The accumulation of aldehydes may be explained by the decrease in activity of a soluble NADP-dependent alcohol dehydrogenase with high affinity for aldehydes. Preliminary results suggested that substances bearing aldehyde groups found in deficient media were substrates for this alcohol dehydrogenase activity.

The amount of protein was slightly lower in $\mathrm{Zn}^{2+}$-starved bacteria and an increased excretion of proteins into the medium was observed; furthermore, a class of proteins precipitable at $\mathrm{pH} 4.5$, which was hardly detectable in normal medium, was present in large amounts in the deficient medium. The immunological activities of the $\mathrm{pH} 4.5$-precipitable proteins liberated into the medium in deficient cultures (De Bruyn et al., 1980) reinforce our interest in pursuing these studies which could also help our understanding of BCG cell wall synthesis.

We are grateful to M. Borremans for help in chemical and enzymic assays and to P. Vanden Bussche for performing the gel electrophoresis. We thank Dr J. M. Ghuysen for helpful discussion.

\section{REFERENCES}

AMEs, B. A. (1966). Assay of inorganic phosphate, total phosphate and phosphatases. Methods in Enzymology 8, 115-118.

BANCE, J. (1942). Contribution a l'ètude comparee des bacilles tuberculeux B.C.G., humain, bovin et aviaire cultives sur milieu de Sauton. Archives de l'Institut Pasteur de Tunis 31, 71-125.

Bergmeyer, H. U., Bernt, E., Möllering, H. \& Pfleiderer, G. (1974). L-Aspartate and Lasparagine. In Methods of Enzymatic Analysis, 2nd edn, vol. 4, pp. 1696-1700. Edited by H. U. Bergmeyer. New York: Academic Press.

BLIGH, E. G. \& DYER, W. J. (1959). A rapid method of total lipid extraction and purification. Canadian Journal of Biochemistry and Physiology 37, 911917.

Charlot, G. (1961). Dosages Colorimétriques des Eléments Mineraux. Paris: Masson et Cie.

Chibnall, R. T., Rees, M. W. \& Williams, E. F. (1943). The total nitrogen content of egg albumin and other proteins. Biochemical Journal 37, 354-359.

Daron, H. H. \& Gunsalus, I. C. (1962). Citritase and isocitritase. Methods in Enzymology 5, 622633.

De Bruyn, J., Huygen, K., Borremans, M., Weckx, M. \& Beumer-Jochmans, M.-P. (1980). Some immunological properties of proteins released in zinc-deficient culture medium of bacillus CalmetteGuerin (BCG). Archives internationales de physiologie et de biochimie 88, B 131.
De BruYn, J., JohanNes, A., WeckX, M. \& BeumerJochmans, M.-P. (1981). Partial purification and characterization of an alcohol dehydrogenase of Mycobacterium tuberculosis var. bovis (BCG). Journal of General Microbiology 124, 359-363.

DREA, W. F. (1956). Traces of zinc in glycerol. American Review of Tuberculosis 74, 145-146.

Holzer, H. \& Goedde, H. W. (1963). Glycolaldehyde determination with yeast alcohol dehydrogenase. In Methods of Enzymatic Analysis, pp. 297-299. Edited by H. U. Bergmeyer. New York: Academic Press.

KARMEN, A. (1955). A note on the spectrophotometric assay of glutamic oxalacetic transaminase in human blood serum. Journal of Clinical Investigation 34, 131-133.

Kotani, S., Kitaura, T., Hirano, T. \& Tanaka, A. (1959). Isolation and chemical composition of the cell walls of BCG. Biken Journal 2, 129-141.

LAEMMLI, U. K. (1970). Cleavage of structural proteins during the assembly of the head of bacteriophage T4. Nature, London 227, 680-682.

MoRrIS, D. L. (1948). Quantitative determination of carbohydrates with Dreywood's anthrone reagent. Science 107, 254-255.

Spector, Th. (1978). Refinement of the Coomassie blue method of protein quantitation. Analytical Biochemistry 86, 142-146. 